\title{
Detection of Pathotypes and Genetic Diversity of Cercospora beticola
}

\author{
Emine Burcu Turgay ${ }^{1}$, Melike Bakır², Pınar Özeren ${ }^{3}$, Yakup Zekai Katırcioğlu³ and Salih Maden ${ }^{3}$ \\ ${ }^{I}$ Central Plant Protection Research Institute, Ministry of Agriculture and Rural Affairs, 06172 Ankara, Turkey \\ ${ }^{2}$ Institute of Biotechnology, Ankara University, 06500 Ankara, Turkey \\ ${ }^{3}$ Department of Plant Protection, Ankara University, 06110 Ankara, Turkey \\ (Received on June 7, 2010; Accepted on October 12, 2010)
}

The pathotypes of Cercospora beticola, causal agent of sugar beet leaf spot disease, were identified by application of pathogenicity test using 100 isolates obtained from the provinces with intensive sugar beet cultivation. For the identification of pathotypes, five sugar beet cultivars were used each with different resistance factors. Cultivar reactions were determined by inoculation of cultivars with the isolates under controlled conditions and measuring disease severity on the $15^{\text {th }}$ day according to the 1-9 KWS Scale. Based on the reactions of the five cultivars, a total of 15 pathotypes were detected. All employed sugar beet cultivars were resistant to Pathotype no: 1 comprising most of the isolates. Genetic diversity of the causal agent was characterized by AFLP reaction. The products acquired at the end of AFLP reaction were detected by means of Beckman CEQ 8800 DNA Capillary Series Analysis and the results obtained were evaluated according to the similarity index UPGMA. For the genetic analysis of $C$. beticola isolates, 9874 polymorphic fragments of sizes between 100 and 500 bp were analysed which were generated by nine primers. The dendrogram derived from AFLP analysis depicted the existence of five different subgroups. The polymorphism rate among isolates was $91.13 \%$ and the dendrogram distribution of the pathotypes obtained by pathogenicity indicated that pathotypes were not discriminated and did not compose any groups.

Keywords : AFLP, Cercospora beticola, genetic diversity, sugar beet, patotype

Cercospora Leaf Spot (CLS) disease of sugar beet caused by the fungus Cercospora beticola (Sacc.) has been accepted as the most destructive and economically damaging foliar disease in hot and humid regions with sugar beet cultivation (Duffus and Ruppel, 1993; Weiland and Koch, 2004). The paathogen has been stated to cause more than 30\% damage in sugar beet fields (Weiland and Koch, 2004). Extensive fungicide application has been performed in order to protect

\footnotetext{
*Corresponding author.

Phone) +90 05359253579, FAX) +90 03123151531

E-mail) cercospora79@gmail.com
}

the sugar beet fields from CLS. In the fields planted with sugar beet cultivars resistant and moderately-tolerant to CLS, fungicides can protect the crops in high disease pressure (Moretti et al., 2006). Due to the facts that the pathogen frequently undergoes genetic change (Ruppel 1972) and the resistance to CLS is controlled qualitatively by a minimum of five loci (Setiawan et al., 2000), today breeders still have difficulty in developing a CLS-resistant sugar beet cultivar. For development of resistant cultivars to be used for the control of the disease, the consideration of genetic diversification of the pathogen and the detection of the pathotypes are extremely important. There are only a few studies worldwide on the detection of the pathotypes (Solel and Wahl, 1971, Ruppel, 1972, Whitney and Lewellen 1974, Lewellen and Whitney, 1976) and genetic diversity (Weiland et al., 2001; Moretti et al., 2004, Vereijssen et al., 2004, Groenevald, 2005) associated with the disease. For this purpose; pathogenicity test and Amplified Fragment Length Polymorphism (AFLP) technique have been applied to $100 \mathrm{C}$. beticola isolates obtained from sugar beet fields with high disease prevalence in the provinces of Thrace, Central Anatolia and Western Black Sea regions in order to detect the pathotypes and genetic diversity of the disease agent.

\section{Materials and Methods}

Obtainment and storage of fungal isolates. The isolates were obtained from the infected samples collected from 24 sugar beet cultivation areas under the domain of seven Turkish sugar factories in 2006. Out of a total 100 isolates, 8 was collected from Alpulu, 22 from Adapazarı, 18 from Amasya, 18 from Çarşamba, 2 from Niksar, 15 from Kastamonu and 19 from Susurluk. Each isolate was obtained from a leaf collected from a diffrent field proportional to the ackerage of the region.

Isolation of $C$. beticola was performed in sugar beet leaf extract agar (SBLEA) (15g agar/litre, 250g fresh leaves/ litre). Small pieces taken from the clean parts of the sporulating lesions from the infected leaves were transferred to the tubes containing $500 \mu 1$ sterile water. Hundred 
$\mu l$ was taken from these tubes and plated on SBLEA agar. Subsequently, the mycelial pieces taken from the sides of the single spore derived colonies were tranferred to the tubes with SBLEA and after growth; they were stored in refrigerator and cryo tubes containing $10 \%$ glycerin at -80 ${ }^{\circ} \mathrm{C}$.

Differential cultivars and their growth. A total of five sugar beet cultivars widely grown in our country were used in our study, namely Arosa and Kassandra with low field resistance, Leila and Evelina with moderate resistance and Visa with high resistance to $C$. beticola. The varieties Arosa, Evelina, Kassandra and Leila were provided from KWS Türk Tarım Ticaret A.Ş.; organize Sanayi Bölgesi 14. Cad. No: 22, 26110, Eskișehir, visa from Sesvanderhave, N. V.; Industriepark Soldantenplein Zone 2, Nr. 15, 3300, Tienen, Belgium). Test plants were grown from the seeds in greenhouse at a temperature of $25 \pm 5^{\circ} \mathrm{C}$ for a duration of 10 weeks (Bargabus et al., 2004).

Preparation of inoculum. Isolates were grown in petri dishes containing SBLEA for a duration of seven days. Inoculum suspension was obtained by removal of the grown fungus from agar surface by means of sterile water containing $0.05 \%$ Tween 20 . The density of this suspension was adjusted to $3 \times 10^{4} \mathrm{spor} / \mathrm{ml}$ by using a Thoma Slide. The prepared inoculum was sprayed onto the sugar beet cultivars until they are completely wet by means of a hand sprayer. Sterile water was given to the plants in the control pots. The inoculated plants were incubated under $95-100 \%$ relative humidity for a duration of four days in humidified, polyethylene growth chambers.

Three leaves were randomly selected from each plant on the $15^{\text {th }}$ day of inoculation, examined for the disease and the disease categories were evaluated according to the 1-9 KWS Scale (Shane and Teng, 1992). For the determination of reactions, sugar beets with a scale value below 5 were accepted as "resistant (R)" while those with a scale value of 5 and above were accepted as "susceptible (S)".

DNA isolation. C. beticola isolates were incubated in 100 ml Potato Dextrose Broth (PDB) medium for a duration of one week in an orbital shaker $(170 \mathrm{rpm})$ at $26 \pm 1^{\circ} \mathrm{C}$ in dark. Total genomic DNA was extraacted according to method of Vilgays and Gonzalez (1990). The pureness and concentrations of DNA's were detected in $1 \%$ agorose gels and with Nanodrop spectrophotometer. Total DNA concent-

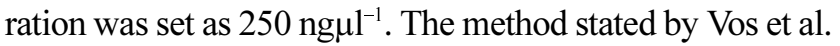
(1995) was employed in AFLP reactions. Genomic DNA $\left(250 \mathrm{ng}^{-1} \mathrm{l}^{-1}\right.$ ) was digested by EcoRI and MseI restriction enzymes and ligated with the addition of appropriate adaptors. Final amplification was realized by means of nine
Table 1. Total and polymorphic DNA bands and polymorphism rates (\%) on Cercospora beticola the causal agent of sugar beet (Beta vulgaris) leaf spot isolates obtained by various primer combinations in AFLP analyses

\begin{tabular}{cccccc}
\hline \hline $\begin{array}{c}\text { Primer } \\
\text { No }\end{array}$ & \multicolumn{2}{c}{$\begin{array}{c}\text { Primer } \\
\text { Combinations }\end{array}$} & $\begin{array}{c}\text { Total } \\
\text { Bands }\end{array}$ & $\begin{array}{c}\text { Polymorphic } \\
\text { Bands }\end{array}$ & $\begin{array}{c}\text { Polymor- } \\
\text { phism (\%) }\end{array}$ \\
\cline { 2 - 4 } & MseI+1 & EcoRI+1 & & 1112 & 92.43 \\
\hline 1 & M-A & E-G & 1203 & 1081 & 95.41 \\
2 & M-C & E-A & 1133 & 1083 & 85.58 \\
3 & M-C & E-C & 985 & 843 & 93.41 \\
4 & M-C & E-T & 1367 & 1277 & 90.36 \\
5 & M-G & E-T & 1110 & 1003 & 93.97 \\
6 & M-G & E-G & 1428 & 1342 & 92.38 \\
7 & M-T & E-A & 985 & 910 & 85.53 \\
8 & M-T & E-C & 1483 & 1313 & 87.02 \\
9 & M-T & E-T & 1141 & 993 & 91.13 \\
\hline
\end{tabular}

selective primer combinations (Table 1). The acquired products were detected by Beckman CEQ ${ }^{\mathrm{TM}} 8800$ Genetic Analysis System with use of sample loading solution and mineral oil of the producer company.

Statistical methods used in the evaluation of results. The differences among pathogenicity levels induced by Cercospora isolates collected from a variety of field sites were analysed by one-way analysis of variance (ANOVA) Kruskal Wallis Test (Kruskal and Wallis, 1952) on the $15^{\text {th }}$ day of the greenhouse experiment.

Following the detection of PCR products by use of the equipment Beckman CEQ 8800 DNA Capillary Series Analysis, the obtained results were scored in electronic medium as "existent (1)" and "non-existent (0)" for each primer pair. The obtained raw data were evaluated by means of MVSP (Multi-Variate Statistical Package, version 3.1) software according to the similarity index UPGMA (Unweighted pair group method with aritmetic averages) of Sorensen (1948). Phylogenetic analyses were also supported by Principle-Co-Ordinate Analysis (PCO).

\section{Results and Discussion}

The fifteen pathotypes obtained by the reactions of $100 C$. beticola isolates on five genetically different cultivars on the $15^{\text {th }}$ day of the inoculation is presented in Table 2. The most prevalent pathotype was Pathotype no: 1. All studied sugar beets were resistant to this pathotype. The second most prevalent pathotype was Pathotype no: 15 which comprised 24 isolates. This pathotype lead to severe disease in all tested sugar beets. The pathotypes noes: 2, 3, 5, 6, 7, 
Table 2. Classified pathotypes of Cercospora beticola the causal agent of sugar beet (Beta vulgaris) leaf spot, on the $15^{\text {th }}$ day of experiment and their distribution

\begin{tabular}{|c|c|c|c|c|c|c|}
\hline \multirow{2}{*}{$\begin{array}{c}\text { Pathotype } \\
\text { No }\end{array}$} & \multicolumn{5}{|c|}{ Cultivars* } & \multirow{2}{*}{ Isolates** } \\
\hline & $\mathrm{A}$ & $\mathrm{K}$ & $\mathrm{L}$ & $\mathrm{E}$ & $\mathrm{V}$ & \\
\hline 1 & $\mathrm{R}$ & $\mathrm{R}$ & $\mathrm{R}$ & $\mathrm{R}$ & $\mathrm{R}$ & $\begin{array}{l}\text { A-1, A-6, AD-2, AD-4, AD-7, AD-9, AD-11, AD-14, AD-20, AD-21, AD-23, AD-25, AM-2, AM- }- \text {, } \\
\text { 4, AM-5, AM-6, AM-10, AM-11, AM-12, AM-13, AM-14, AM-16, AM-17, AM-18, AM-20, Ç, } \\
\text { Ç-3, C--4, Ç-6, Ç-9, Ç-13, Ç-16, K-6, S-2, S-3, S-4, S-5, S-6, S-7, S-8, S-10, S-11, S-13, S-15, S-16, } \\
\text { S-19, S-21 Total 47 }\end{array}$ \\
\hline 2 & $\mathrm{R}$ & $\mathrm{R}$ & $\mathrm{S}$ & $\mathrm{R}$ & $\mathrm{R}$ & K-9 \\
\hline 3 & $\mathrm{R}$ & $\mathrm{R}$ & $\mathrm{R}$ & $\mathrm{S}$ & $\mathrm{R}$ & $\mathrm{N}-24$ \\
\hline 4 & $\mathrm{R}$ & $\mathrm{S}$ & $\mathrm{R}$ & $\mathrm{R}$ & $\mathrm{R}$ & AM-3, AD-22, S-12 \\
\hline 5 & $\mathrm{R}$ & $\mathrm{S}$ & $\mathrm{S}$ & $\mathrm{S}$ & $\mathrm{R}$ & A-5 \\
\hline 6 & $\mathrm{R}$ & $\mathrm{S}$ & $\mathrm{S}$ & $\mathrm{S}$ & $\mathrm{S}$ & $\mathrm{K}-4$ \\
\hline 7 & $\mathrm{~S}$ & $\mathrm{R}$ & $\mathrm{S}$ & $\mathrm{S}$ & $\mathrm{S}$ & $\mathrm{K}-11$ \\
\hline 8 & $\mathrm{~S}$ & $\mathrm{R}$ & $\mathrm{R}$ & $\mathrm{R}$ & $\mathrm{R}$ & A-9, AM-1, AM-7, AM-8, N-21, N-23 \\
\hline 9 & $\mathrm{~S}$ & $\mathrm{R}$ & $\mathrm{S}$ & $\mathrm{R}$ & $\mathrm{R}$ & AD-18, S-1 \\
\hline 10 & $\mathrm{~S}$ & $\mathrm{~S}$ & $\mathrm{R}$ & $\mathrm{S}$ & $\mathrm{R}$ & K-12, Ç-1, S-18 \\
\hline 11 & $\mathrm{~S}$ & $\mathrm{~S}$ & $\mathrm{R}$ & $\mathrm{S}$ & $\mathrm{S}$ & AD-26 \\
\hline 12 & $\mathrm{~S}$ & $\mathrm{~S}$ & $\mathrm{R}$ & $\mathrm{R}$ & $\mathrm{R}$ & AD-1 \\
\hline 13 & $\mathrm{~S}$ & $\mathrm{~S}$ & $\mathrm{~S}$ & $\mathrm{R}$ & $\mathrm{S}$ & A-3, AM-15, Ç-8, K-7, K-13 \\
\hline 14 & $\mathrm{~S}$ & $\mathrm{~S}$ & $\mathrm{~S}$ & $\mathrm{~S}$ & $\mathrm{R}$ & AD-8, K-15, AD-12 \\
\hline 15 & $\mathrm{~S}$ & $\mathrm{~S}$ & $\mathrm{~S}$ & $\mathrm{~S}$ & $\mathrm{~S}$ & $\begin{array}{l}\text { A-2, A-7, A-8, AD-10, AD-15, AD-17, AD-19, AD-24, AD-27, AM-9, Ç-7, Ç-10, Ç-11, Ç-12, Ç- } \\
\text { 14, Ç-15, K-1, K-2, K-5, K-8, K-10, K-14, K-16, S-20 Total } 24\end{array}$ \\
\hline
\end{tabular}

*Cultivars: A stands for Arosa; $\mathrm{K}$ for Kassandra; L for Leila; E for Evelina and V for Visa.

**Regions of Isolates: A stands for Alpullu; AD for Adapazarl; AM for Amasya; Ç for Çarşamba; K for Kastamonu; N for Niksar and S for Susurluk.

11 and 12 were represented by a single isolate. When the pathogenicity results were compared with the dendrogram, it was found that the obtained pathotypes could not be clustered under any groups. There was not any agreement between the pathogenicity results and the dendrogram. These findings revealed that molecular techniques have failed to discriminate among $C$. beticola pathotypes. This fact is also valid for other pathogens. If a pathogen has a high genetic diversity, the pathotypes can not be easily discriminated by molecular techniques. Likewise, a Ph.D. study on Ascochyta rabiei (Pass) Labr. of Chickpea conducted at Ankara University Faculty of Agriculture Plant Protection Department proved that molecular techniques were unsuccessful for discrimination of the pathotypes of the agent Ascochyta rabiei (unpublished Ph.D. thesis). Similar results were also obtained from studies on Fusarium oxysporum (Zamani et al., 2004) and Alternaria solani (Van der Waals et al., 2004). The attainment of such results in the studies on a variety of other pathogens support that the primers used in our study were natural and appropriate in terms of selectivity-selection (Weising et al., 1995). However, the genetic characteristics of pathotypes do not display significant differences with respect to the other genetic characteristics of associated pathogens or there are not any appropriate primers to discriminate among these characteristics.

The differences among pathogenicity levels induced by Cercospora isolates on sugar beet cultivars were analysed by ANOVA Kruskal Wallis Test. In accordance with the results, 28 isolates (A-2, A-3, AD-26, AD-27, AM-1, AM9, AM-16, Ç-1, Ç-2, Ç-8, Ç-11, Ç-15, N-21, N-24, K-1, K4, K-9, K-10, K-12, K-13, K-15, S-7, S-11, S-12, S-15, S$17, \mathrm{~S}-18, \mathrm{~S}-19)$ were found to have generated significant differences $(p \leq 0.05)$ in terms of pathogenicity which varied among the regions. When the isolates of the same region were compared, no agreements were identified among associated pathogenicity results. For example, while AM-1 isolate collected from Amasya Province has shown the expected effect in the sugar beets with low, moderate and high resistance levels, AM-9 isolate from the same region has not exhibited any statistically significant differences among levels of pathogenicity induced in susceptible, moderately and highly resistant sugar beets. A similar case was observed in the pathogenicity findings associated with the isolates collected from Çarşamba District. Some of the isolates (AD-27, AM-9, Ç-15, K-1, K-10) have not generated statistically significant differences in terms of pathogenicity levels. However, these isolates were covered within 
Pathotype no:15 which lead to severe CLS.

The identified difference of 28 eight isolates among pathogenicity potentials of the isolates of diverse regions indicated that diverse $C$. beticola isolates show dissimilar pathogenicity reactions even though they were isolated from places with same or similar geographical-climatic conditions or with same or similar applied agricultural practices. This fact supports the findings of former studies from different country-specific conditions all concluding about "the highly variable pathogenicity pattern of $C$. beticola" (Ruppel 1972; Whitney and Lewellen 1976). Additionally, susceptibility of the cultivars to AD-27, AM9 , Ç-15, K-1, K-10 isolates in our study once more confirmed the ability of the pathogen to undergo a rapid genetic change and break down the resistance of resistant cultivars. Furthermore, Nilsson et al. (1999) studied inheritance of resistance to $C$. beticola and mapped five QTL (Quantitative Trait Loci) locations for resistance. These five locations constituted $18 \%$ of the inherent locations for resistance and $37 \%$ of such locations could not be identified. This fact explains that resistance to $C$. beticola is managed by multiple genes and the pathogen displays high genetic variation.

The employed DNA fingerprinting technique confirmed high genetic diversity among isolates based on high diversity of genes and genotypes associated with the tested $C$. beticola isolates. Similar findings were reported by other studies on $C$. beticola by use of the RAPD, AFLP and DAMD-PCR techniques (Weiland et al., 2001; Moretti et al., 2004) and on other pathogens which are assumed to have an asexual mode of reproduction (Salamati et al., 2000; Goodwin et al., 2003; Van der Waals et al., 2004). These findings are also in agreement with the identified high genetic diversity of $C$. beticola as confirmed by the applied pathogenicity test for the detection of $C$. beticola pathotypes and AFLP analysis results.

As indicated by the dendrogram of Sorensen similarity index (Fig. 1), while Cluster 1 covers a single isolate and two subgroups, Cluster 2 comprises six subgroups; each of which is further subdivided into five subgroups, namely A, $\mathrm{B}, \mathrm{C}, \mathrm{D}$ and $\mathrm{E}$. The lowest similarity rate $(0.423)$ was detected between the isolates Kastamonu-1 and Adapazar127 whereas the highest rate $(0.822)$ was calculated between the isolates Kastamonu-15 and Kastamonu-16.

PCO reveals the distribution of samples within space dimension but is rather concerned with the distributions in the first and second coordinates. The results of the basic coordinate analysis also indicate that genotypes are divided into two major groups each of which is further subdivided into of five subgroups (Fig. 2). The first major group is depicted in the left upper corner (A and $\mathrm{B}$ ) and the second at the right upper and bottom corners (C, D and E). Considering the coordinate distribution of isolates with respect

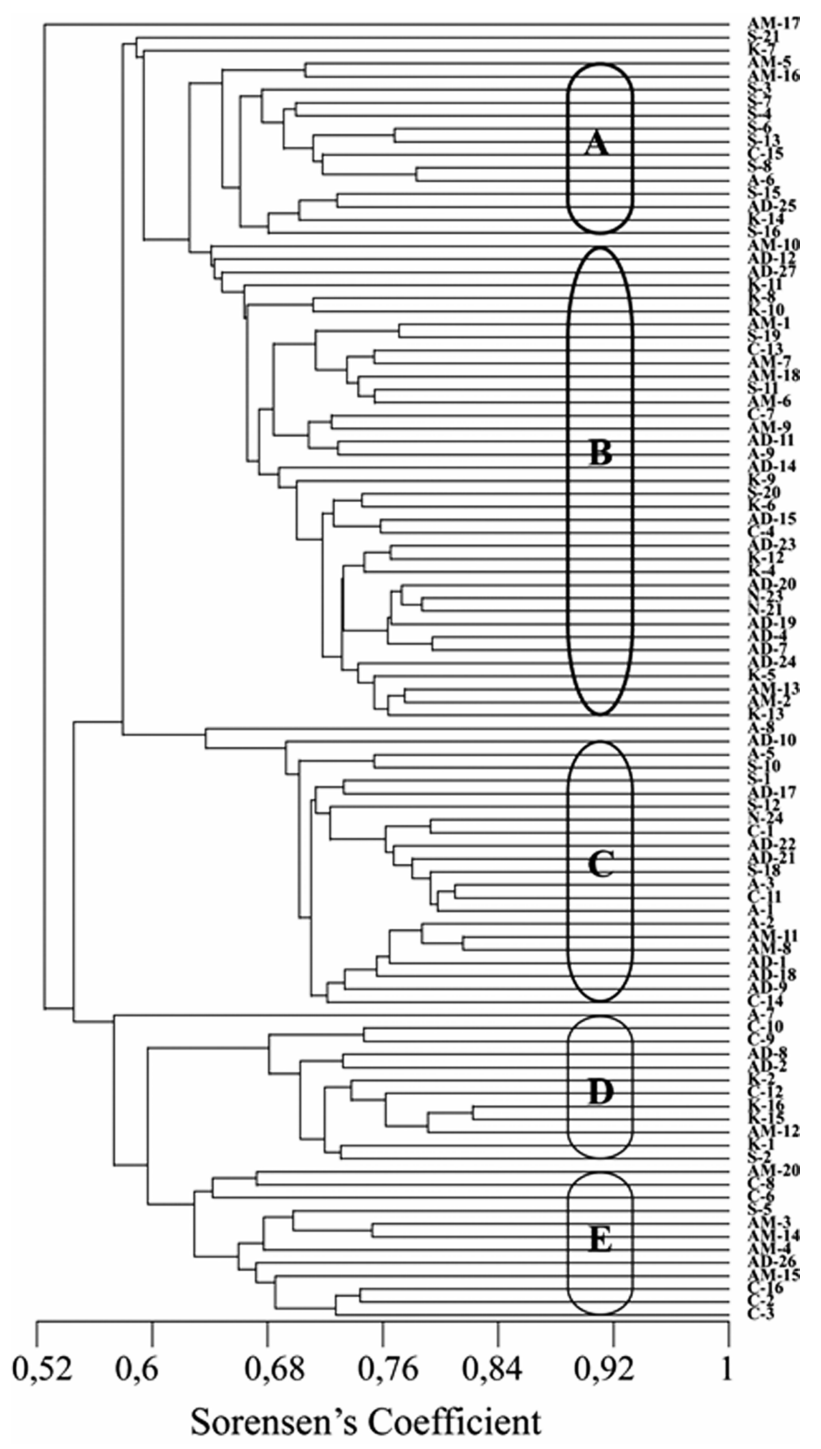

Fig. 1. Dendogram showing the distribution of the isolates of sugar beet (Beta vulgaris) leaf spot disease caused by Cerscospora beticola, the causal agent of sugar beet (Beta vulgaris) leaf spot on basis of Unweighted pair group method with aritmetic averages cluster analysis.

to regions and pathotypes, it is seen that isolates were neither grouped on the basis of region nor on the basis of pathotypes but rather composed mixed groupings.

For the genetic analysis of $C$. beticola isolate reproductions, 9874 polymorphic fragments were analysed with sizes ranging between 100 and 500 bp (Fig. 3). Out of a total of 10835 DNA fragments comprising isolates collected from same and different regions, 9874 were identified as polymorphic and 961 as monomorphic. The number of polymorphic fragment positions per primer pair combination ranged between 843 and 1342. Polymorphism rate among isolates was determined as $91.13 \%$ (Table 1). 


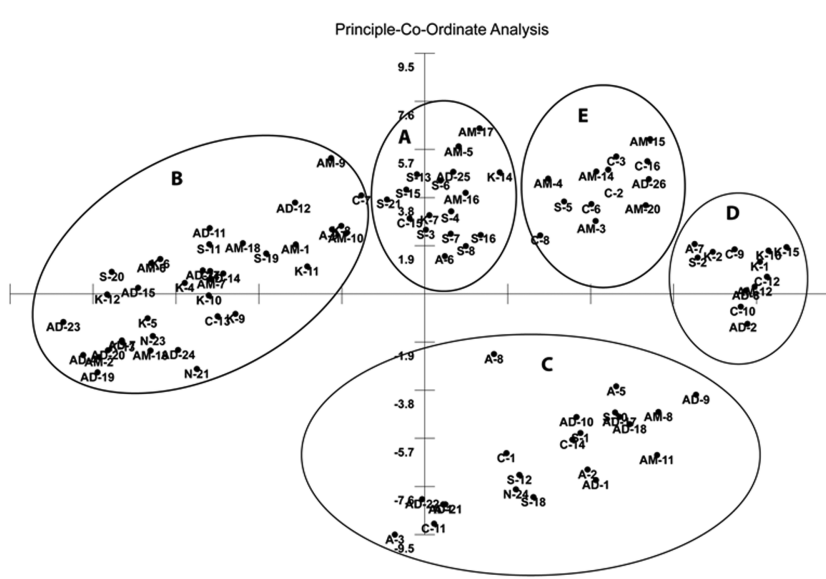

Fig. 2. Principle-Co-Ordinate Analysis of AFLP patterns of Cerscospora beticola, the causal agent of sugar beet (Beta vulgaris) leaf spot by use of different primer combinations.

The genetic structure of $C$. beticola populations obtained from six different regions of Turkey did not exhibit any region-specific variations and almost all of the genetic diversity $(91.13 \%)$ was distributed within the population. This indicates that the populations separated by hundreds of kilometers of borders represent a diverse epidemiological unit with a genetically different and country-wide spread gene flow.

Considering C. beticola, it is thought that conidia are primarily responsible for the disease and spread by splashing effect of heavy rain. Due to the fact that the conidia having the potential for long-distance spread is limited in this study, high diversification levels associated with $C$. beticola populations are not expected. Nevertheless, no findings could be detected regarding any particular group formation of pathotypes along a territory of hundreds kilometers.

In order to balance the lack of regional characterization of C. beticola populations, it is necessary to recognize the existence of long-distance spread. As stated by Vereijssen (2004), the spread can occur by contaminated seeds or by human activities. Sugar beet seeds in Turkey are produced

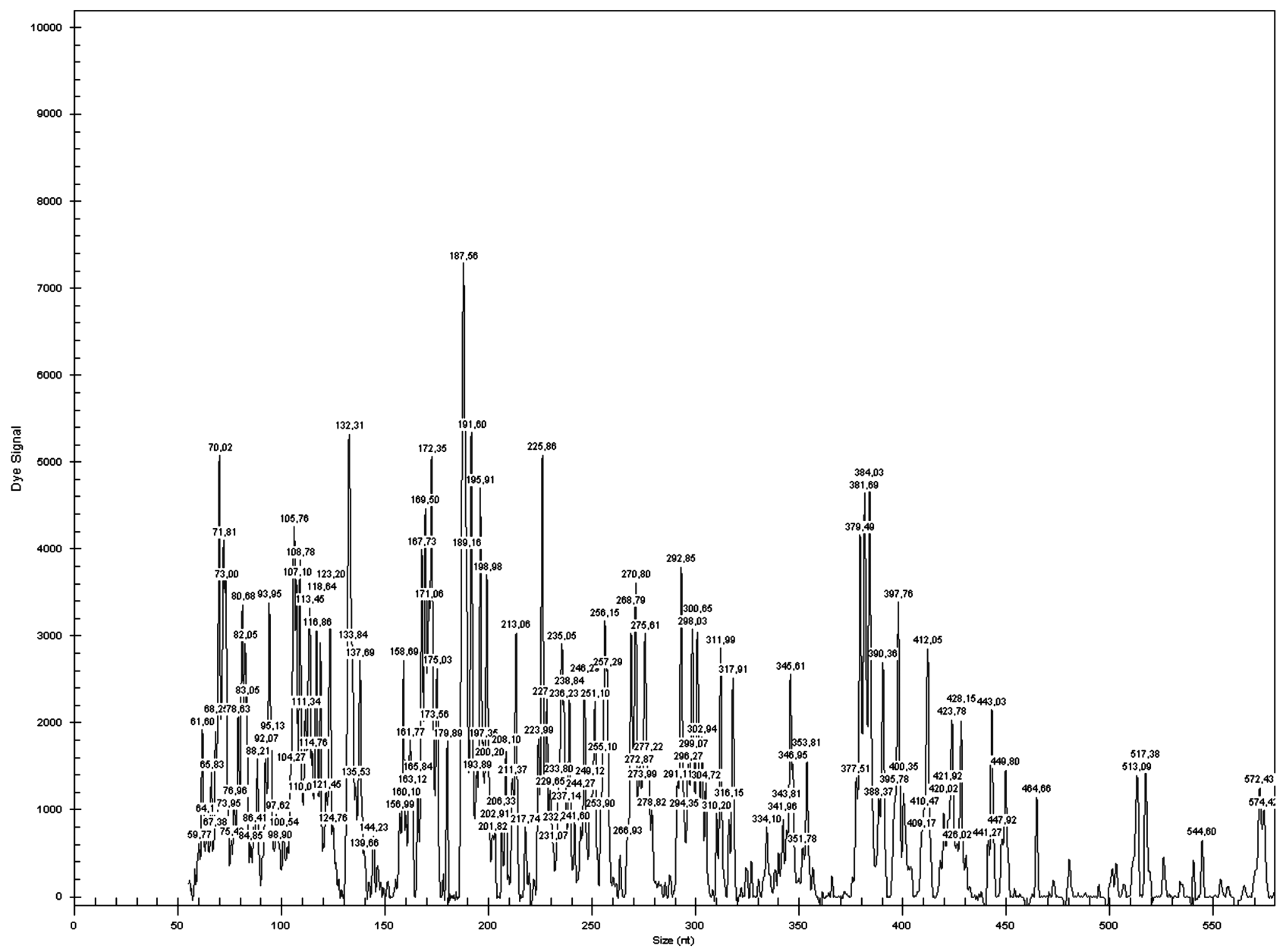

Fig. 3. Fragments generated by analysis of AFLP analysis analyzed in Beckman CEQ 8800 DNA Capillary Series Analysis. 
in specific fields and distant from commercial sugar beet cultivation areas and they are disseminated to the producers across the country. Seed transmission of pathogen is well known and seed producing areas are contaminated by the pathogen. For this reason distribution of the disease by this way could provide genetic diversity. Furthermore, in all regions of sugar beet cultivation, same harvest machinery are used during harvest time which enables the interregional spread of the pathogen by transport of waste plants containing conidia and stroma.

Besides, it is reported that $C$. beticola which is assumed to be an individually and asexually growing fungus, has exhibited a high genotypic diversity among limited number of clonal (phenotypically very close) lines (Milgroom, 1996). Observed high diversity among the tested $C$. beticola isolates points out the existence of a factor encouraging genome change. The mentioned factor can be a hyphal anastomosis followed by a parasexual recombination or an elusive mating system as well (Weiland and Koch, 2004). In cases without sexual recombination, the continuation of genetic diversity in natural populations can be attributed to parasexual cycle (Sanders, 1999).

The prerequisite for parasexual recombination is the possibility of nucleus change through hyphal anastomosis which actually was revealed in the study of Cai and Schneider (2005) about heterokaryon formation possibility among strains in Cercospora kikuchii fungus. The studies on the determination of such characteristic associated with $C$. beticola are in progress. On the other hand, the hypothesis which states that the pathogen undergoes an unobservable sexual reproduction (Goodwin et al., 2003) but the recombinations can only be evaluated by testing linkage disequilibriums among loci (Milgroom, 1996) also needs to be considered. Such analyses require higher amounts of samples and more specific reproduction strategies.

Okori et al. (2004) stated that the lack of genetic diversification in C. sorghi populations might be attributed to wild Sorghum plants in gene flow. We suggest that studies for further clarification of the role of sugar beet progenitor (Beta vulgaris spp. maritima) shall be conducted in order to identify the probable determinants of $C$. beticola gene flow among sugar beet fields in Turkey.

Sugar beet leaf spot caused by Cercospora beticola is a serious disease which occurs on one third of the total sugar beet growing area of 315,000 ha, in Turkey (Ozgur, 2003). $C$. beticola shows great pathogenic variation and this situation creates difficulty in determination of resistant varieties especially in field conditions which is usual procedure in many countries as well as in Turkey. For development of resisitant cultivars to be used in control of disease, the consideration of genetic diversification of pathogen and the detection of the pathotypes are extremely important. In order to improve the selection process, pathotypes of $C$. beticola should be determined. The pathotypes of the disease were investpgated by employing pathogenicity on genetically different cultivars and by genetic characterization of the isolates by AFLP. Depending on pathogenecity tests 15 pathotypes were differentiated, pathotype 15 being the most aggressive one and represented by 24 isolates. This method might allow pathologists everywhere to determine the pathotypes of $C$. beticola, especially the most agressive isolates. AFLP analyses of 100 isolates revealed that pathotypes could not be differentiated by this method since pathotypes represented by more than 5 isolates took place in various places of the dendogram generated by this method.

As a result, it is not simple to detect and characterize the pathotypes of CLS either by classical or molecular methods. The high diversity associated with Cercospora species seems to be a rule rather than an exception. The breeding programs established for the production of CLS-resistant sugar beet cultivars consider the resistance ability of the pathogens to the control methods. Hence, the clarification of these mechanisms is very important in practical sense. The mechanisms that enable and sustain the genetic diversity of the fungus is still a largely unknown topic which should be highlighted with nucleotide seqence-based phylogenetic analysis as further investigations.

\section{Acknowledgement}

I would like to extend my thanks to The Scientific and Technological Research Center of Turkey (TUBITAK) for its funding within the scope of Project No: 105O121, to Assoc. Prof. Dr. Ali ERGÜL for his supports.

\section{References}

Bargabus, R. L., Zidack, N. K., Sherwood, J. E. and Jacobsen, B. J. 2004. Screening for the identification of potential biological control agents that induce systemic acquired resistance in sugar beet. Biological. Control 30:342-350.

Cai, G. and Schneider, R. W. 2005. Vegetative compatibility groups in Cercospora kikuchii, the causal agent of cercospora leaf blight and purple seed stain in soybean. Phytopathology 95:257-261.

Duffus, J. E. and Ruppel, E. G. 1993. Disease. In: Cooke D.A., Scott R.K., Eds, The Sugar Beet Crop. Chapman and Hall. London, pp. 347-427.

Groenewald, M., Groenewald, J. Z. and Crous, P. W. 2005. Distinct species exist within the Cercospora apii morphotype. Phtopathology 95:951-959.

Goodwin, S. B., Waalwijk, C., Kema G. H. J., Cavaletto, J. R. and Zhang, G. 2003. Cloning and analysis of the mating-type idiomorphs from the barley pathogen Septoria passerinii. Mol. 
Genet. Genomics 269:1-12.

Kruskal, W. H. and Wallis, W. A. 1952. Use of ranks in one-criterion variance analysis. Journal of the American Statistical Association 47:583-621.

Lewellen, R. T. and Whitney, E. D. 1976. Inheritance of resistance to race C2 of C. beticola in sugar beet. Crop. Sci. 16:558-561.

Milgroom, M. G. 1996. Recombination and the multilocus structure of fungal populations. Ann. Rev. Phytopathol 34:457-477.

Moretti, M., Saracchi, M. and Farina, G. 2004. Morphological, physiological and genetic diversity within a small population of Cercospora beticola Sacc. Ann. Microbiol. 54:129-150.

Moretti, M., Karaoglanıdıs, G., Saracchı, M., Fontana, A. and Farrina, G. 2006. Analysis of genotypic diversity in Cercospora beticola Sacc. field isolates. Annals of Microbiology 56:215221.

Nilsson, N. O., Hansen, M., Panagopoulos, A. H., Tuvesson, S., Ehlde, M., Christiansson, M., Rading, I. M., Rissler, M. and Kraft, T. 1999. QTL analysis of Cercospora leaf spot resistance in sugar beet. Plant Breeding 118:327-334.

Okori, P., Rubaihayo, P. R., Ekwamu, A., Fahleson, J. and Dixelius, C. 2004. Genetic characterization of Cercospora sorghi from cultivated and wild sorghum and its relationship to other Cercospora fungi. Phytopathology 94:743-750.

Ozgur, O. E. (Sugar beet disease in Turkey, TSFAS, Filiz Matbaası, Ankara.Yayın No. 219, 2003, pp. 192). (In Turkish).

Ruppel, E. G. 1972. Variation among isolates of Cercospora beticola from sugar beet. Phytopathology 62:134-136.

Salamati, S., Zhan, J., Burdon, J. J. and McDonald, B. A. 2000. The genetic structure of field populations of Rhynchosporium secalis from three continents suggests moderate gene flow and regular recombination. Phytopathology 90:901-908.

Sanders, I. 1999. No sex please, we are fungi. Nature 399:737739.

Setiawan, A., Koch, G., Barnes, S. R. and Jung, C. 2000. MApping quantitative trait loci (QTL) for resistance to Cercospora leaf spot disease (Cercospora beticola Sacc.) in sugarbeet. Theor. Appl. Genet. 100:1176-1182.

Shane, W. W. and Teng, P. S. 1992. Impact of Cercospora leaf spot on root weight, sugar yield, and purity of Beta vulgaris. Plant Dis. 76:812-820.

Solel, Z. and Wahl, I. 1971. Pathogenic Specialization of C. beticola. Phytopathology 61:1081-1083.

Sorensen, T. 1948. A method of establishing groups of equal amplitude in plant sociology based on similarity of species content and its application to analyses of the vegetation on Danish commons. Vidensk Selsk Biol. Skr. 5:1-34.

Van der Waals, J. E., Korsten, L. and Slippers, B. 2004. Genetic diversity among Alternaria solani isolates from potatoes in South Africa. Plant Dis. 88:959-964.

Vereijssen, J. 2004. Cercospora leaf spot in sugar beet. Epidemiology, life cycle components and disease management. Wageningen, The Netherlands, Wageningen University, PhD Thesis.

Vilgalys, R. and Gonzalez, D. 1990. Ribosomal DNA restriction fragment length polymorphisms in Rhizoctonia solani. Phytopathology 80:151-158.

Vos, P., Hogers, R., Bleeker, M., Reijans, M., Vander Lee, T., Hones, M., Frijters, A. and Pot, J. 1995. AFLP: a new technique for DNA fingerprinting. Nucleic Acids Res. 23:44074414.

Weiland, J., Eide, J., Rivera-Varas, V. and Secor, G. 2001. Genetic diversity of Cercospora beticola in the U.S. and association of molecular markers with tolerance to the fungicide triphenyltin hydroxide (TPTH). Phytopathology 91: 94.

Weiland, J. and Koch, G. 2004. Sugarbeet leaf spot disease (Cercospora beticola Sacc.). Mol. Plant Pathology 5:157-166.

Weising, K., Nybom, H., Wolff, K. and Meyer, W. Eds. 1995. DNA fingerprinting in plants and fungi. CRC Press, Boca Raton USA (ISNB: 0-8493-8920-8).

Whitney, E. D. and Lewellen, R. T. 1974. Physiological race of Cercospora beticola on Beta vulgaris Proc. Am. Phytopathol. Soc. 1:88-89.

Zamani, M. R., Motallebi, M. and Rostamian, A. 2004. Characterization of Iranian isolates of Fusarium oxysporum on the basis of RAPD analysis, pathogenicity, and vegetative compatibility. J. Phytopathol. 152:499-503. 